water bodies in Alberta, are no longer valuable as bird sanctuaries. This view is based on sketchy data and, in our opinion, reflects a lack of understanding and research into the dynamics or aquatic habitats in the grassland region.

From published information and conversations with local residents, it appears that Pakowki Lake dries up completely perhaps as much as $50 \%$ of the time." However, there are usually some remnants of aquatic habitats even in the driest years. The high capability of the lake during periods of high water levels appears to offset the non-productive dry years. It seems likely that the bird life of this and similar areas has adapted to the dramatic fluctuations in the water levels.

Further diking of fields which keeps spring melt water from entering the normal drainage channels that feed the lake, and the diversion of the inflowing water for irrigation are real dangers to the water regime of Pakowki Lake. It is our wish that this preliminary report will draw attention to the significance of Pakowki Lake and to ensure its further protection as a sanctuary. In addition, it is hoped that this will stimulate other investigations into the bird life of other large water bodies in the grassland region, especially those which are threatened with loss of sanctuary status or facing disruption through recreational or agricultural activities.

Pakowki Lake is an area that contains a great deal of interest for naturalists, and is well worth a visit. The authors would greatly appreciate and duly acknowledge, any observations concerning the natural history of Pakowki Lake. This, along with more intensive field study, will enable us to present a more complete picture of the natural history of the area.

'SALT, W. R. and A. L. WILK 1966. The Birds of Alberta (second edition). Queen's Printer, Edmonton.

${ }^{2}$ SOPER, J. D. 1939. Report on Pakowki Lake Bird Sanctuary, Alberta (unpublished). Dept. of Mines and Res., National Parks Bureau, Ottawa.

\section{A JULY DAY AT LAST MOUNTAIN LAKE}

KEN LUMBIS, 1008 - 3rd Street, Saskatoon, Saskatchewan and BOB GODWIN, 2237 Broadway Avenue, Saskatoon, Saskatchewan.

This is a list of 82 species of birds observed in 7 hours on July 2, 1976, at the north end and northwest side of Last Mountain Lake, east of Simpson, Saskatchewan. Kathy Meeres, Kim Godwin and the authors visited the fingers, Etter's Beach, the Headquarters area, Basin A, Sailor's Bay and several farmyards between 11:30 a.m. and $6: 30$ p.m. It rained in the morning, there was scattered cloud in the afternoon, a light breeze and it was about $15^{\circ} \mathrm{C}$.

Two Red-necked Grebes, 2 Horned Grebes, 5 Pied-billed Grebes, 2 pairs with 1 young each of Western Grebes, 4 White Pelicans, 4 Doublecrested Cormorants, 1 Great Blue Heron, 1 Black-crowned Night Heron, 6 American Bitterns, many Mallards, several Gadwalls, many Pintails, several Green-winged Teal, many Bluewinged Teal, many American Wigeon, many Northern Shovelers, several, mostly male, Redheads, 1 Ring-necked Duck, several, mostly male, Canvasbacks, many Lesser Scaup, 3 Buffleheads, several White-winged Scoters, many Ruddy Ducks, 2 Swainson's Hawks, 1 Marsh Hawk, several Soras, many American Coots, many Killdeer, 3 Upland Plovers, 2 Solitary Sandpipers, many Willets, several Greater Yellowlegs, many Lesser Yellowlegs, 1 Least Sandpiper, 12 Dowitchers, several Marbled Godwits, 2 American Avocets, 2 male Wilson's Phalaropes, 1 California Gull, 2 Ring-billed Gulls, 5 Franklin's Gulls, many Forster's Terns, many Common Terns, many Black Terns, many Rock Doves, several Mourning Doves, 1 Black-billed Cuckoo, I Short-eared Owl, I Common Flicker.

Many Eastern Kingbirds, 3 plus 1 pair nesting Western Kingbirds, many Horned Larks, 2 Tree Swallows, 4 Bank Swallows, at least 2 pairs nesting Barn Swallows, many Black-billed Magpies, many Crows, 3 plus 1 pair of nesting House Wrens, 1 Short-billed Marsh Wren, 3 Brown Thrashers, 1 Sprague's Pipit, several Loggerhead Shrikes, several Yellow Warblers, 3 Common Yellowthroats, many House Sparrows, 1 male Boblink, many Western Meadowlarks, many Yellow-headed Blackbirds, many Red-winged Blackbirds, many Brewer's Blackbirds, many Common Grackles, many Brown-headed Cowbirds, several American Goldfinches, many Savannah Sparrows, I Grasshopper Sparrow, several Baird's Sparrows, 3 Sharp-tailed Sparrows, many Vesper Sparrows, 2 Chipping Sparrows, many clay-coloured Sparrows, many Song Sparrows, 1 male Chestnut-collared Longspur. 